\title{
Superoxide dismutase activity and gene expression levels in Saudi women with recurrent miscarriage
}

\author{
HAZEM K. GHNEIM ${ }^{1}$, YAZEED A. AL-SHEIKH ${ }^{1}$, MASHAEL M. ALSHEBLY ${ }^{2}$ and MOURAD A. M. ABOUL-SOUD ${ }^{1}$ \\ ${ }^{1}$ Chair of Medical and Molecular Genetics, Department of Clinical Laboratory Sciences, \\ College of Applied Medical Sciences, King Saud University, Riyadh 11433; ${ }^{2}$ Department of Obstetrics and Gynecology, \\ College of Medicine, King Saud University, Riyadh 11472, Kingdom of Saudi Arabia
}

Received November 11, 2015; Accepted January 25, 2016

DOI: $10.3892 / \mathrm{mmr} .2016 .4807$

\begin{abstract}
The antioxidant activities of superoxide dismutase 1 (SOD1) and SOD2, as well as the levels of the oxidant superoxide anion (SOA) and the micronutrients zinc ( $\mathrm{Zn}$ ), copper $(\mathrm{Cu})$ and manganese $(\mathrm{Mn})$, were assayed in plasma, whole blood and placental tissue of non-pregnant (NP), healthy pregnant (HP) women and recurrent miscarriage (RM) patients. The results showed that SOD1 and SOD2 activities and the levels of $\mathrm{Zn}, \mathrm{Cu}$ and $\mathrm{Mn}$ in plasma and whole blood of $\mathrm{HP}$ women were slightly, but significantly lower, and even more significantly decreased in RM patients compared to those observed in NP women ( $\mathrm{P}<0.05$ and $\mathrm{P}<0.0001$, respectively). Additionally, whereas plasma SOD1 and SOD2 activities and $\mathrm{Zn}, \mathrm{Cu}$ and $\mathrm{Mn}$ levels were significantly lower in RM patients, those of whole blood and placental tissue were significantly lower when compared to HP women $(\mathrm{P}<0.001$ and $\mathrm{P}<0.0001$, respectively). Concurrently, there were consistent increases of equal magnitude and statistical significance in SOA levels in all the assayed samples as identified by a comparison between the subjects. The findings thus supported oxidative metabolism and excessive reactive oxygen species generation. The resultant oxidative stress, identified in whole blood and placental tissues of RM patients, may have been a primary cause of RM. Dietary supplementation of $\mathrm{Zn}, \mathrm{Cu}$ and $\mathrm{Mn}$ may be beneficial to these patients pre- and post-conception.
\end{abstract}

\section{Introduction}

Reactive oxygen species (ROS) are produced following single electron reduction of molecular oxygen. One to $2 \%$ of the oxygen consumed by cells escapes from the mitochon-

Correspondence to: Dr Hazem K. Ghneim, Chair of Medical and Molecular Genetics, Department of Clinical Laboratory Sciences, College of Applied Medical Sciences, King Saud University, PO Box 10219, Riyadh 11433, Kingdom of Saudi Arabia E-mail: hghneim@hotmail.com

Key words: recurrent miscarriage, superoxide dismutase, superoxide anions, placental tissue, blood, micronutrients drial respiratory chain and is converted into highly reactive species (1). Although physiological concentrations of ROS in aerobic organisms are beneficial as they are involved in cell signaling pathways and survival from invading pathogens, accumulation of such species, known as oxidative stress (OS), can contribute to the development of various diseases (1), including pregnancy-associated ones (2). Diseases are caused by incurring indiscriminate damage causing alteration of cellular macromolecules such as membrane lipids, DNA, proteins and alteration in gene expression, including apoptosis-related genes $(3,4)$. In addition, ROS affect cell function through changes in intracellular calcium or $\mathrm{pH}$ which can eventually lead to cell death (5).

Under physiological conditions the most common ROS are the superoxide anions (SOA) created from molecular oxygen by the addition of an electron. SOA lack the ability to penetrate lipid membranes and are thus confined to the compartment in which they are generated (6). The formation of SOA occurs spontaneously especially in an electron-rich environment in the vicinity of the inner mitochondrial membrane and the respiratory chain (6) as a result of the leakage of 1-3\% of electrons being transported along the chain enzymes. Similarly, SOA are generated through electron leakage from the shorter electron transport chain within the endoplasmic reticulum (7). The formation of disulphide bonds during protein folding is an oxidative process and $25 \%$ of SOA are generated within cells in the endoplasmic reticulum. Other sources of SOA include the enzyme nicotinamide adenine dinucleotide phosphate (NADPH) oxidase which constitutes a major source of the anions in neutrophils, vascular endothelial cells and vascular smooth muscle $(8,9)$. This oxidase is known to produce substantial quantities of SOA throughout pregnancy and particularly in early pregnancy (10). Additional SOA sources include cytochrome P450, xanthine oxidase and other oxidoreductases (11).

SOA constitute the initial step in the formation and propagation of ROS intra- and extracellularly, and is the precursor of most ROS, and is therefore a mediator in oxidation reactions. The anti-oxidant defense of aerobic cells begins by dismutation of SOA into hydrogen peroxide by the action of superoxide dismutase (SOD) which is considered to play a fundamental role against oxidant generation. Three distinct forms of SOD have been identified in mammals. Two of these forms, SOD1 
and SOD3, have copper $(\mathrm{Cu})$ and zinc $(\mathrm{Zn})$ in their catalytic center and are localized in the intracellular cytoplasmic compartments including the cytosol, nuclear compartments and lysosomes, SOD1, or extracellular SOD3 (12). A third SOD has manganese $(\mathrm{Mn})$ as a cofactor, SOD2 and is located in the mitochondria (13).

Recurrent miscarriage (RM), is strictly defined as the occurrence of $\geq 3$ consecutive pregnancy losses prior to 24 weeks of gestation (14), and affects $1-3 \%$ of pregnancies (15). The etiologies of RM include parental chromosomal abnormalities, uterine anomalies, autoimmune diseases, thyroid pathologies, blood clotting disorders, infectious diseases, endocrinopathies and environmental factors (14-17). RM causes are identified in $50 \%$ of patients, and the remaining $50 \%$ is idiopathic (16). However, mounting evidence suggests that OS and loss of antioxidant capacity in utero-placental tissues are important in the development of placental and pregnancy-related diseases including RM, preeclampsia and intrauterine growth restriction $(2,14,18-20)$. To this end, it has been shown that OS causes impaired placental development and apoptosis of syncytotrophoblast leading to RM $(2,21)$.

Recent reports (27) have demonstrated significantly lower activity levels of enzymatic and non-enzymatic antioxidants in plasma, whole blood and/or placental tissue of RM patients including glutathione peroxidase, catalase, glutathione reductase, reduced glutathione and selenium (22-26). The reports also indicated concurrent significant increases in oxidant levels including hydrogen peroxide, oxidized glutathione and malondialdehyde. However, studies associating SOD activity in RM patients are scarce. Only two studies $(24,28)$ demonstrated a significant decrease in plasma SOD activities of such patients following a comparison with healthy pregnant (HP) women. Furthermore, there are no studies associated with the corresponding levels of SOA in such patients. Thus, the present study was undertaken to examine SOD1 and SOD2 activities and the related $\mathrm{Zn}, \mathrm{Cu}$ and $\mathrm{Mn}$ micronutrients levels, as well as SOA generation rates in plasma, whole blood and placental tissue of RM patients and their comparison with non-pregnant (NP) and HP women. In addition, the present study examined the mRNA expression levels of SOD1 in the placental tissue of RM patients compared to those of HP women.

\section{Materials and methods}

Subjects. The current study population was the same one used in our previous study (27), and comprised three groups of women: Those who were NP $(n=15)$, those who were HP $(n=25)$ and those who suffered from RM $(n=25)$. NP and HP subjects did not have a history of any reproductive disease and subjects of all three groups were age-matched. Details regarding age means, gestational age of RM patients at the time of abortion, average number of abortions and hemoglobin values of all the subjects were identical to those recorded in our previous study (27). Blood and placental tissue samples were collected shortly after delivery for HP women, or at the time of abortion for RM patients. Ethics approval was obtained from the Institutional Review Board of the College of Medicine, King Saud University (project $\neq$ E-13-920, approval letter $\neq 14 / 4001 /$ IRB, June 2014). Written informed consent was obtained from each of the study subjects.
Sample collection and preparation. Venous blood sample were obtained from all the subjects and placed into EDTA-chilled tubes for the assays used to assess SOD1 and SOD2 activities and SOA generation, or into polyethylene terephthalate tubes for $\mathrm{Zn}, \mathrm{Cu}$ and $\mathrm{Mn}$ determination. Plasma, whole blood suspensions and hemolysates and placental tissue supernatants were prepared as previously described (27). Samples used for $\mathrm{Zn}, \mathrm{Cu}$, and $\mathrm{Mn}$ analysis required preparation as described below.

SOD1 and SOD2 assays. SOD1 and SOD2 activities were assayed in all the samples according to de Haan et al (29) and as previously modified by us (30). Total SOD activity was measured by the addition of previously 1:10 diluted plasma $(250 \mu \mathrm{l})$, blood hemolysate $(100 \mu \mathrm{l})$ or placental tissue supernatant $(50 \mu \mathrm{l})$ to xanthine $(25 \mu \mathrm{l}, 1.142 \mathrm{mg} / \mathrm{ml})$, hydroxyl ammonium chloride $(25 \mu \mathrm{l})$, water $(125 \mu \mathrm{l})$ and xanthine oxidase $(0.1 \mathrm{U} / \mathrm{ml}, 75 \mu \mathrm{l})$. The mixture was then incubated at $25^{\circ} \mathrm{C}$ for $20 \mathrm{~min}$, and sulphonilic acid $(0.5 \mathrm{ml}, 3.3 \mathrm{mg} / \mathrm{ml})$ and $\alpha$-naphthylamine $(0.5 \mathrm{ml}, 1 \mathrm{ng} / \mathrm{ml})$ were added and further incubated at a room temperature of $25^{\circ} \mathrm{C}$ for $20 \mathrm{~min}$ and absorbance was read at $530 \mathrm{~nm}$ using an Ultrospec 2100 pro UV/VIS Spectrophotometer (Amersham Biosciences, Piscataway, NJ, USA). The addition of potassium cyanide (125 $\mu \mathrm{l}, 4 \mathrm{mM}$ ) instead of water specifically inhibited SOD1 activity. Thus, subtraction of the activity remaining after the addition of potassium cyanide (SOD2) from total SOD activity yielded SOD1 activity.

SOA assay. SOA generation in all the samples was determined by modification of the method of Johnston et al (31). Plasma $(50 \mu \mathrm{l})$, blood hemolysate $(100 \mu \mathrm{l})$ or placental tissue supernatant $(50 \mu \mathrm{l})$ were incubated for $5 \mathrm{~min}$ at $37^{\circ} \mathrm{C}$ with phosphate-buffered saline (potassium phosphate $10 \mathrm{mM}$ and sodium chloride $150 \mathrm{mM}, \mathrm{pH} 7.4,1 \mathrm{ml}$ ) containing glucose $(2 \mathrm{~g} / \mathrm{l})$ and fatty acid-free bovine serum albumin $(2 \mathrm{~g} / \mathrm{l})$ with or without SOD $(30 \mu \mathrm{g}, 50 \mu \mathrm{l})$. To initiate the reaction, ferricytochrome $\mathrm{C}$ solution $(1.2 \mathrm{mM}, 100 \mu \mathrm{l})$ was added to the incubation mixture, and the increase in absorbance was monitored at $550 \mathrm{~nm}$ in a recording thermostated spectrophotometer (Shimatzu model UV-2401 PC, Dubai, United Arab Emirates). SOA generation was determined by calculating the difference between the sample without SOD and that with added SOD. Tubes containing only buffer and ferricytochrome c were incubated as mentioned above and run as blanks. The results were expressed as the amount of reduced ferricytochrome $\mathrm{c}$ in $\mathrm{nmol} / \mathrm{min} / \mathrm{ml}$ for plasma and whole blood or $\mathrm{nmol} / \mathrm{min} / \mathrm{mg}$ for placental tissue.

$\mathrm{Zn}, \mathrm{Cu}$ and Mn assays. Plasma, blood hemolysate and placental supernatant samples were freeze-dried at $-45^{\circ} \mathrm{C}$ and pulverized. The samples were than digested with ultra-pure nitric acid $(0.5 \mathrm{ml}, 68 \%)$ and hydrogen peroxide $(0.2 \mathrm{ml}, 35 \%)$. Clear and colorless digests were appropriately diluted with ultra-pure water and assayed for $\mathrm{Zn}, \mathrm{Cu}$ and $\mathrm{Mn}$ using inductively coupled plasma mass spectrometry (HP 4500; Yokokawa Electric Co., Kanazawa, Japan) according to Osada et al (32). Analytical accuracy was checked using standards obtained from the National Institute of Standards and Technology (Gaithersburg, MD, USA). 
Table I. Superoxide dismutase (SOD1 and SOD2) activities and superoxide anion (SOA) generation in plasma, whole blood and placental tissue of non-pregnant (NP), healthy pregnant (HP) women and recurrent miscarriage (RM) patients.

Subjects

\begin{tabular}{lccc} 
Samples assayed and units & NP women, $\mathrm{n}=15$ & HP women, $\mathrm{n}=25$ & RM patients, $\mathrm{n}=25$ \\
\hline Plasma SOD1, nmol/min/ml & $6.69 \pm 0.84$ & $6.11 \pm 0.73^{\mathrm{a}}$ & $5.43 \pm 0.69^{\mathrm{b}, \mathrm{c}}$ \\
Whole blood SOD1, U/g Hb & $602 \pm 84.1$ & $542 \pm 74.7^{\mathrm{a}}$ & $333 \pm 45.9^{\mathrm{b}, \mathrm{d}}$ \\
Placental SOD1, $\mu \mathrm{mol} / \mathrm{min} / \mathrm{mg}$ protein & - & $3.42 \pm 0.44$ & $1.81 \pm 0.23^{\mathrm{d}}$ \\
Plasma SOD2, nmol/min/mg & $5.59 \pm 0.72$ & $5.12 \pm 0.66^{\mathrm{a}}$ & $4.50 \pm 0.55^{\mathrm{b}, \mathrm{c}}$ \\
Whole blood SOD2, U/g Hb & $504 \pm 62.5$ & $460 \pm 60.2^{\mathrm{a}}$ & $278 \pm 37.7^{\mathrm{b}, \mathrm{d}}$ \\
Placental SOD2, $\mu \mathrm{mol} / \mathrm{min} / \mathrm{mg}$ protein & - & $2.86 \pm 0.37$ & $1.51 \pm 0.20^{\mathrm{d}}$ \\
Plasma SOA, $\mathrm{nmol} / \mathrm{ml}$ & $178 \pm 22.2$ & $197 \pm 24.7^{\mathrm{a}}$ & $223 \pm 27.80^{\mathrm{b}, \mathrm{c}}$ \\
Whole blood SOA, nmol/ml & $241 \pm 30.9$ & $263 \pm 34.2^{\mathrm{a}}$ & $407 \pm 50.7^{\mathrm{b}, \mathrm{d}}$ \\
Placental SOA, nmol/min/mg & - & $28.1 \pm 3.58$ & $47.7 \pm 5.96^{\mathrm{d}}$ \\
\hline
\end{tabular}

${ }^{\mathrm{a}} \mathrm{P}<0.05$ when comparing results of all the parameters in the plasma of HP against those obtained for NP women. ${ }^{\mathrm{b}} \mathrm{P}<0.0001$ when comparing results of all parameters in plasma and whole blood of RM patients against those obtained for NP women. ${ }^{\mathrm{c}} \mathrm{P}<0.001$ when comparing results of all parameters in plasma of RM patients against those obtained for HP women. ${ }^{\mathrm{d}} \mathrm{P}<0.0001$ when comparing results of all parameters in whole blood and placental tissue of RM patients against those obtained for HP women.

Gene expression profiling of hsSOD1 using reverse transcription quantitative polymerase chain reaction (RT-qPCR). Placental tissue $(100 \mathrm{mg})$, which had been freshly collected and stored in RNAlater ${ }^{\circledR}$ RNA Stabilization Solution (Qiagen, Hilden, Germany) at $-80^{\circ} \mathrm{C}$, was homogenized using a TissueLyser LT (Qiagen) in $1.0 \mathrm{ml} \mathrm{TRIzol}{ }^{\circledR}$ Reagent (Invitrogen Life Technologies, Paisley, UK) and total RNA was extracted according to standard procedures. The quality and quantity of the purified RNA was determined by a Qubit ${ }^{\circledR} 2.0$ flurometer using the Qubit RNA assay kit. To eliminate any contaminating genomic DNA, a gDNA wipeout reaction was undertaken in a wipeout buffer at $42^{\circ} \mathrm{C}$ for $2 \mathrm{~min}$. cDNA was synthesized from RNA $(1 \mu \mathrm{g})$ in a final reaction volume $(20 \mu \mathrm{l})$ using the QuantiTect Reverse Transcriptase kit (QuantiTect ${ }^{\circledR}$; Qiagen), according to the manufacturer's instructions. The resultant diluted cDNA (1:10, $5 \mu \mathrm{l})$, was used to perform RT-qPCR by the QuantiTect SYBR-Green PCR kit (Qiagen) and the SOD Qiagen Primer Assay (Hs_SOD_1_SG QuantiTect Primer assay, QTO1664327) in a final reaction volume (25 $\mu \mathrm{l})$ containing the diluted cDNA sample $(5 \mu \mathrm{l}), 2 \mathrm{X}$ SYBR-Green PCR Master Mix (12.5 $\mu \mathrm{l})$, forward and reverse primer $(10 \mu \mathrm{M}$ stock, $2.5 \mu \mathrm{l})$ and RNAase-free water $(2.5 \mu \mathrm{l})$.

Following an initial polymerase activation at $95^{\circ} \mathrm{C}$ for $10 \mathrm{~min}$, the samples were subjected to 40 cycles of denaturation at $95^{\circ} \mathrm{C}$ for $15 \mathrm{sec}, 55^{\circ} \mathrm{C}$ for $30 \mathrm{sec}$ and $72^{\circ} \mathrm{C}$ for $30 \mathrm{sec}$. Following amplification, the specificity of the product was assessed from a melting curve program in a three-segment cycle of $95^{\circ} \mathrm{C}$ for $0 \mathrm{sec}, 65^{\circ} \mathrm{C}$ for $15 \mathrm{sec}$ and $95^{\circ} \mathrm{C}$ for $0 \mathrm{sec}$ at the continuous acquisition mode. Each placental tissue sample was represented by biological replicas and three technical replicas, with the inclusion of a no-template control. Raw data were analyzed using the Rotor-Gene cycler software version 2.3 to calculate the threshold cycle using the second derivative maximum. The fold change in each gene was determined after normalization to the expression levels of $18 \mathrm{~S}$ as a housekeeping gene as previously described (33).
Other assays and statistical analysis. Total protein content of samples $(20 \mu \mathrm{l})$, was assayed according to Bradford (34). Drabkin's reagent was used to measure hemoglobin concentration in blood hemolysates as previously described (27).

Statistical analysis was performed using the statistical package for social sciences software (SPSS version 17.0; SPSS, Inc., Chicago, IL, USA). Sample analysis was run in duplicate for all the investigated parameters and results were presented as means \pm standard deviation. Values of the activities and levels of individual parameters were compared between groups of the study using one-way analysis of variance followed by the post hoc Tukey-HSD test. $\mathrm{P}<0.05$ was considered to indicate a statistically significant difference.

\section{Results}

SOD1 and SOD2 activities and SOA generation in plasma, whole blood and placental tissue of NP, HP and RM women. Table I data clearly indicate that SOD1 plasma and whole blood activities in HP women were slightly decreased $(6.11 \pm 0.73 \mathrm{nmol} / \mathrm{min} / \mathrm{ml}$ and $542 \pm 74.7 \mathrm{U} / \mathrm{g} \mathrm{Hb}$, respectively), and much more significantly decreased in RM patients $(5.43 \pm 0.69 \mathrm{nmol} / \mathrm{min} / \mathrm{ml}$ and $333 \pm 45.9 \mathrm{U} / \mathrm{g} \mathrm{Hb}$, respectively), when both were compared to the enzyme's activities identified for NP women $(6.69 \pm 0.84 \mathrm{nmol} / \mathrm{min} / \mathrm{ml}$ and $602 \pm 84.1 \mathrm{U} / \mathrm{g}$ $\mathrm{Hb}$, respectively; $\mathrm{P}<0.05$ and $\mathrm{P}<0.0001)$. In addition, whereas SOD1 plasma activity was significantly decreased in RM patients $(5.43 \pm 0.69 \mathrm{nmol} / \mathrm{min} / \mathrm{ml})$ when compared to that in $\mathrm{HP}$ women $(6.11 \pm 0,73 \mathrm{~mol} / \mathrm{min} / \mathrm{ml} ; \mathrm{P}<0.001)$, it was much more significantly lower in whole blood of the same patients when compared to HP women ( $333 \pm 45.9$ against $542 \pm 74.7 \mathrm{U} / \mathrm{g}$ $\mathrm{Hb} ; \mathrm{P}<0.0001)$. A similar reduction in the enzyme's placental tissue activity in RM patients was observed following a comparison with that obtained in HP women $(1.81 \pm 0.23$ against $3.42 \pm 0.44 \mu \mathrm{mol} / \mathrm{min} / \mathrm{mg}$ protein; $\mathrm{P}<0.0001)$. Similar to SOD1, plasma and whole blood SOD2 activities in HP women were 
Table II. Zinc (Zn), Copper (Cu) and Manganese (Mn) levels in plasma, whole blood and placental tissue of non-pregnant (NP), healthy pregnant (HP) women and recurrent miscarriage ( RM) patients.

Subjects

\begin{tabular}{lccc} 
Samples assayed and units & NP women, $\mathrm{n}=15$ & HP women, $\mathrm{n}=25$ & RM patients, $\mathrm{n}=25$ \\
\cline { 2 - 4 } Plasma $\mathrm{Zn}, \mu \mathrm{mol} / \mathrm{l}$ & $4.47 \pm 0.58$ & $4.11 \pm 0.49^{\mathrm{a}}$ & $3.67 \pm 0.39^{\mathrm{b}, \mathrm{c}}$ \\
Whole blood Zn, $\mu \mathrm{mol} / \mathrm{l}$ & $5.89 \pm 0.77$ & $5.39 \pm 0.70^{\mathrm{a}}$ & $3.50 \pm 0.46^{\mathrm{b}, \mathrm{d}}$ \\
Placental tissue ZnSOD1, nmol/g & - & $685 \pm 85.8$ & $466 \pm 60.5^{\mathrm{d}}$ \\
Plasma Cu, $\mu \mathrm{mol} / \mathrm{l}$ & $31.6 \pm 3.79$ & $28.8 \pm 3.42^{\mathrm{a}}$ & $25.60 \pm 3.25^{\mathrm{b}, \mathrm{c}}$ \\
Whole blood Cu, $\mu \mathrm{mol} / \mathrm{l}$ & $41.3 \pm 5.16$ & $37.8 \pm 4.54^{\mathrm{a}}$ & $24.50 \pm 2.93^{\mathrm{b}, \mathrm{d}}$ \\
Placental tissue Cu, nmol/g & - & $108 \pm 13.70$ & $67.40 \pm 8.09^{\mathrm{d}}$ \\
Plasma $\mathrm{Mn}, \mathrm{nmol} / \mathrm{l}$ & $53.9 \pm 6.47$ & $48.9 \pm 5.63^{\mathrm{a}}$ & $43.70 \pm 5.10^{\mathrm{b}, \mathrm{c}}$ \\
Whole blood Mn, nmol/l & $69.3 \pm 9.00$ & $63.1 \pm 8.07^{\mathrm{a}}$ & $40.50 \pm 5.09^{\mathrm{b}, \mathrm{d}}$ \\
Placental tissue Mn, $\mathrm{nmol} / \mathrm{g}$ & - & $7.49 \pm 0.89$ & $5.42 \pm 0.68^{\mathrm{d}}$
\end{tabular}

${ }^{\mathrm{a}} \mathrm{P}<0.05$ when comparing the results of all parameters in plasma of HP against those obtained for NP women. ${ }^{\mathrm{b}} \mathrm{P}<0.0001$ when comparing the results of all parameters in plasma and whole blood of RM patients against those obtained for $\mathrm{NP}$ women. ${ }^{\mathrm{C}} \mathrm{P}<0.001$ when comparing the results of all parameters in plasma of RM patients against those obtained for HP women. ${ }^{\mathrm{d}} \mathrm{P}<0.0001$ when comparing the results of all parameters in whole blood and placental tissue of RM patients against those obtained for HP women.

moderately lower in HP women $(5.12 \pm 0.66 \mathrm{nmol} / \mathrm{min} / \mathrm{ml}$ and $460 \pm 60.2 \mathrm{U} / \mathrm{g} \mathrm{Hb}$, respectively), and much more significantly lower in RM patients $(4.50 \pm 0.55 \mathrm{nmol} / \mathrm{min} / \mathrm{ml}$ and $278 \pm 37.7 \mathrm{U} / \mathrm{g}$ $\mathrm{Hb}$, respectively), when the results were compared to the enzyme's activities recorded for NP women $(5.59 \pm 0.72 \mathrm{nmol} / \mathrm{min} / \mathrm{ml}$ and $504 \pm 62.5 \mathrm{U} / \mathrm{g} \mathrm{Hb}$, respectively; $\mathrm{P}<0.05$ and $\mathrm{P}<0.0001$ ).

Furthermore, although SOD2 plasma activity was significantly decreased in RM patients $(4.50 \pm 0.55 \mathrm{nmol} / \mathrm{min} / \mathrm{ml})$ when compared to that in HP women $(5.12 \pm 0.66 \mathrm{nmol} / \mathrm{min} / \mathrm{ml}$; $\mathrm{P}<0.001$ ), it was much more significantly decreased in whole blood of the same patients when compared to HP women $(278 \pm 37.7$ against $460 \pm 60.2 \mathrm{U} / \mathrm{g} \mathrm{Hb} ; \mathrm{P}<0.0001)$. Similarly, SOD2 placental tissue activity in RM patients was highly significantly lower than that identified in HP women $(1.51 \pm 0.20$ against $2.86 \pm 0.37 \mu \mathrm{mol} / \mathrm{min} / \mathrm{mg}$ protein; $\mathrm{P}<0.0001)$.

Concurrent with the above decrease in SOD1 and SOD2 activities, Table I data indicate that SOA generation levels underwent slight but significant increases in the plasma and whole blood of HP women $(197 \pm 24.7$ and $263 \pm 34.2 \mathrm{nmol} / \mathrm{ml}$, respectively), and much more significant increases in RM patients $(223 \pm 27.8$ and $407 \pm 50.7 \mathrm{nmol} / \mathrm{ml}$, respectively) when both were compared to those obtained for NP women (178 \pm 22.2 and $241 \pm 30.9 \mathrm{nmol} / \mathrm{ml}$, respectively) $(\mathrm{P}<0.05$ and $\mathrm{P}<0.0001)$. In addition, although plasma SOA levels were significantly increased in $\mathrm{RM}$ patients $(223 \pm 27.8 \mathrm{nmol} / \mathrm{min})$ when compared with those generated in HP women $(197 \pm 24.7 \mathrm{nmol} / \mathrm{min}$; $\mathrm{P}<0.001)$, the whole blood SOA levels of the same patients were much more significantly increased $(407 \pm 50.7 \mathrm{nmol} / \mathrm{ml})$ when compared to those of HP women $(263 \pm 34.2 \mathrm{nmol} / \mathrm{ml}$; $\mathrm{P}<0.0001)$. Furthermore, the placental tissue SOA levels of RM patients $(47.7 \pm 5.96 \mathrm{nmol} / \mathrm{min} / \mathrm{mg})$ were significantly increased when compared to those documented for HP women $(28.1 \pm 3.58 \mathrm{nmol} / \mathrm{min} / \mathrm{mg} ; \mathrm{P}<0.0001)$.

$\mathrm{Zn}, \mathrm{Cu}$ and Mn levels in plasma, whole blood and placental tissue of NP, HP and RM women. Parallel to the reduced SOD1 and SOD2 levels identified above, Table II data clearly show that, whereas plasma and whole blood $\mathrm{Zn}$ levels of HP women were slightly decreased $(4.11 \pm 0.49$ and $5.39 \pm 0.70 \mu \mathrm{mol} / 1$, respectively), these levels were much more significantly reduced in RM patients $(3.67 \pm 0.39$ and $3.50 \pm 0.46 \mu \mathrm{mol} / 1$, respectively) when compared to those documented for NP women $(4.47 \pm 0.58$ and $5.89 \pm 0.77 \mu \mathrm{mol} / 1$, respectively; $\mathrm{P}<0.05$ and $\mathrm{P}<0.0001)$. In addition, although plasma $\mathrm{Zn}$ levels were significantly reduced in RM patients $(3.67 \pm 0.39 \mu \mathrm{mol} / \mathrm{l})$ when compared to those in HP women $(4.11 \pm 0.49 \mu \mathrm{mol} / \mathrm{l}$; $\mathrm{P}<0.001)$, the whole blood $\mathrm{Zn}$ levels of the same patients $(3.50 \pm 0.46 \mu \mathrm{mol} / \mathrm{l})$ were much more significantly decreased than those recorded for HP women $(5.39 \pm 0.70 \mu \mathrm{mol} / \mathrm{l}$; $\mathrm{P}<0.0001)$. Similarly the placental $\mathrm{Zn}$ levels of $\mathrm{RM}$ patients were very significantly reduced $(466 \pm 60.5 \mathrm{nmol} / \mathrm{g})$ when compared to those obtained for HP women $(685 \pm 85.8 \mathrm{nmol} / \mathrm{g}$; $\mathrm{P}<0.0001)$.

$\mathrm{Cu}$ level variations in the analyzed samples exhibited similar patterns and statistical magnitudes as those observed for $\mathrm{Zn}$ (Table II). Plasma and whole blood $\mathrm{Cu}$ levels of HP women were slightly reduced (28.8 \pm 3.42 and $37.8 \pm 4.54 \mu \mathrm{mol} / 1$, respectively), and much more significantly lowered in RM patients $(25.60 \pm 3.25$ and $24.50 \pm 2.93 \mu \mathrm{mol} / 1$, respectively) when compared to NP women (31.6 \pm 3.79 and $41.3 \pm 5.16 \mu \mathrm{mol} / 1, \mathrm{P}<0.05$ and $\mathrm{P}<0.0001$, respectively). Furthermore, although plasma $\mathrm{Cu}$ levels were significantly reduced in RM patients $(25.60 \pm 3.25 \mu \mathrm{mol} / \mathrm{l})$ when compared to HP women $(28.8 \pm 3.42 \mu \mathrm{mol} / 1 ; \mathrm{P}<0.001)$, the whole blood $\mathrm{Cu}$ levels of RM patients $(24.50 \pm 2.93 \mu \mathrm{mol} / \mathrm{l})$ were much more significantly lower than those observed for HP women $(37.8 \pm 4.54 \mu \mathrm{mol} / 1 ; \mathrm{P}<0.0001)$. Similarly, the placental tissue $\mathrm{Cu}$ levels of RM patients were significantly lower $(67.40 \pm 8.09 \mathrm{nmol} / \mathrm{g})$ when compared to those for HP women $(108 \pm 13.70 \mathrm{nmol} / \mathrm{g} ; \mathrm{P}<0.0001)$.

Results shown in Table II also indicate that plasma and whole blood Mn levels in HP women were slightly lower 


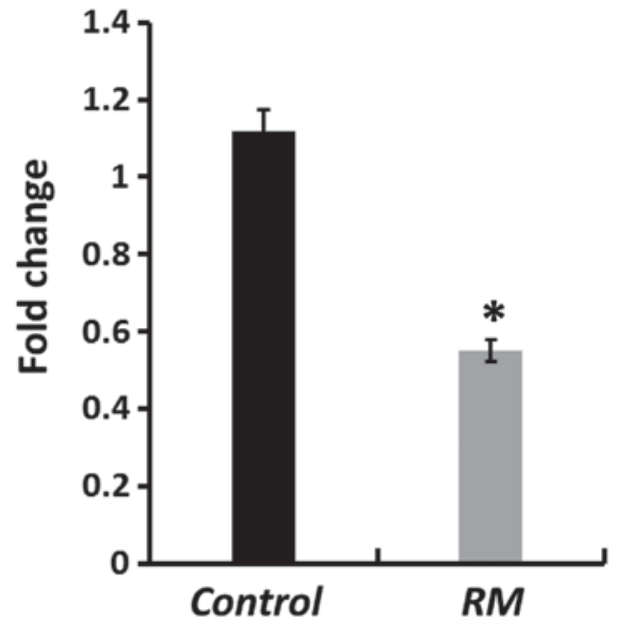

Figure 1. Relative gene expression of hsSOD1 in placental tissues of Saudi women with recurrent miscarriage (RM) compared to healthy pregnant (HP) controls. ${ }^{*} \mathrm{P}<0.001$ when comparing gene expression levels in placental tissues of RM patients relative to HP controls.

(48.9 \pm 5.63 and $63.1 \pm 8.07 \mathrm{nmol} / 1$, respectively), and much more significantly decreased in RM patients $(43.70 \pm 5.10$ and $40.50 \pm 5.09 \mathrm{nmol} / 1$, respectively) following a comparison of both those observed for NP women $(53.9 \pm 6.47$ and $69.3 \pm 9.00 \mathrm{nmol} / 1$, respectively; $\mathrm{P}<0.05$ and $\mathrm{P}<0.0001)$. In addition, although plasma $\mathrm{Mn}$ levels were significantly lower in RM patients $(43.70 \pm 5.10 \mathrm{nmol} / \mathrm{l})$ when compared to those observed in HP women $(48.9 \pm 5.63 \mathrm{nmol} / \mathrm{l} ; \mathrm{P}<0.001)$, the whole blood $\mathrm{Mn}$ levels of the same patients $(40.5 \pm 5.09 \mathrm{nmol} / \mathrm{l})$ were much more significantly decreased than those recorded for HP women $(63.1 \pm 8.07 \mathrm{nmol} / \mathrm{l} ; \mathrm{P}<0.0001)$. Similarly, the placental tissue Mn levels of RM patients were significantly decreased $(5.42 \pm 0.68 \mathrm{nmol} / \mathrm{g})$ when compared to those of HP women $(7.49 \pm 0.89 \mathrm{nmol} / \mathrm{g} ; \mathrm{P}<0.0001)$.

Gene expression of hSSOD1 in placental tissue of HP and RM women. Fig. 1 shows that, the intracellular hsSOD1 transcripts were found significantly downregulated by almost $54 \%$ in placental tissues of RM patients as compared to HP women $(\mathrm{P}<0.0001)$.

\section{Discussion}

Pregnancy presents a condition of metabolic challenge for the mother and the developing fetus, and has been associated with increased OS in HP women compared to the NP state $(27,35)$. The placenta is regarded as a key source of this OS (36), as it has been shown to exhibit low antioxidant enzyme activities especially during the first trimester, making the syncytotrophoblast vulnerable to oxygen-mediated damage and increased apoptosis (22). At commencement of the second trimester, oxygen tension increases 3 -fold in the intervillous space with the onset of maternal arterial flow thus causing an increase in placental OS (36). This oxidative injury alters placental remodeling and function and affects the course of gestation. Abnormal placentation and the resultant endothelial dysfunction (37) have been shown to cause pregnancy disorders including RM $(2,14,18-22)$. In healthy pregnancy, however, ROS generation is controlled by enzymatic and non-enzymatic antioxidants and OS is mini- mized (27), ensuring healthy placental function and normal development, growth and delivery of the fetus. By contrast, recent findings (27), have shown significantly decreased activities and levels of enzymatic and non-enzymatic antioxidants including SOD, glutathione peroxidase, catalase, glutathione reductase, reduced glutathione, selenium, vitamins A and $\mathrm{E}$ and $\beta$ carotene, which was coupled with an increased generation of oxidants including hydrogen peroxide, lipoperoxides and oxidized glutathione in plasma and/or whole blood and placental tissue of RM patients in comparison with HP women (23-27).

Antioxidant and oxidant status have been suggested as useful tools in the assessment of oxidative damage, and may be used in the design of strategies for the management of OS-related pregnancy disorders. To this end, the present study was undertaken to examine SOD1 and SOD2 activities and SOA levels in plasma, whole blood and placental tissue of RM patients in comparison with those obtained in NP and HP women. Antioxidant defenses are initiated by quenching and removal of SOA through SOD activity, which catalyzes the dismutation of the anion into hydrogen peroxide, followed by the action of catalase and glutathione peroxidase which further degrade hydrogen peroxide into water. Thus, SOD activity is regarded as a first line of defense and has a fundamental role in combating OS. Although hydrogen peroxide is not a free radical, it is able to penetrate cell membranes and interact with SOA leading to the generation of the more toxic and reactive hydroxyl radicals via the Haber-Weiss and Fenton reactions $(38,39)$. The latter reacts with purines and pyrimidines causing DNA damage (40). Results of the present study indicated significant increases in SOA generation in the plasma of RM patients, and much more significant ones in whole blood and placental tissue of the same patients compared to HP women $(\mathrm{P}<0.001$ and $\mathrm{P}<0.0001$, respectively). This result was likely caused by the parallel equally significant decreases identified in SOD1 and SOD2 activities. In a previous study (27), we identified equally significant increases in hydrogen peroxide generation rates in whole blood and placental tissue of the same RM patients investigated in concurrence with significantly lowered glutathione peroxide and catalase activities. These increases in the SOA and hydrogen peroxide concentrations may have resulted in the generation of large amounts of hydroxyl ions, causing subsequent reduced gene expression of the antioxidant enzymes, excessive OS and miscarriage in these patients. Although many studies, including our previous study, have demonstrated significantly decreased glutathione peroxidase and catalase activities in plasma, whole blood and/or placental tissue of RM patients in comparison with HP women (23-27,41), only two studies have examined total SOD activity in such patients $(24,28)$, and none were related to SOA levels, thereby marking the importance of the findings of the present study.

Pregnancy is regarded as an exceptional condition of enhanced demand for various micronutrients and vitamins including selenium, zinc, copper, manganese and vitamins C, E and B12 (42). Physiological and metabolic changes of pregnant women as well as increased demands for these micronutrients by the developing fetus, causes a decrease in their bioavailability (42), and may lead to pregnancy complications. $\mathrm{Cu}, \mathrm{Zn}$ and $\mathrm{Mn}$ are important cofactors of many enzymes including 
$\mathrm{Cu} / \mathrm{Zn}$-SOD (SOD1) and Mn-SOD (SOD2), which protect the placenta from SOA generation and initiation of OS (42). In the current study, we were able to observe significant decreases in plasma $\mathrm{Zn}$ and $\mathrm{Cu}$ levels, and much more significant ones in whole blood and placental tissue of RM patients compared to HP women $(\mathrm{P}<0.001$ and $<0.0001$, respectively). In addition, the plasma levels of these micronutrients underwent moderate but significant decreases in HP women compared to NP women $(\mathrm{P}<0.05)$. These findings are in agreement with those reported by other authors $(25,26,43,44)$. In this context many authors have reported a decrease in plasma $\mathrm{Zn}$ levels as pregnancy progresses especially since $\mathrm{Zn}$ is used for the development of fetal brain $(45,46)$. By contrast, those authors reported significant increases in plasma $\mathrm{Cu}$ concentration during pregnancy before returning to normal NP values post-delivery. This result may be partly associated with the fact that almost $96 \%$ of plasma $\mathrm{Cu}$ during pregnancy is bound to its carrier protein ceruloplasmin which is synthesized in large quantities in response to elevated estrogen levels or to counteract anemia since this protein has ferroxidase properties (45-48). In the current study, free cationic $\mathrm{Zn}$ and $\mathrm{Cu}$ levels underwent significant decreases in whole blood and the placental tissue of RM patients, which may have constituted a major causative factor for the observed significant reduction in SOD1 activity, and the simultaneous increase in SOA concentrations and OS, thus leading to miscarriage. This total SOD activity was shown to decrease in $\mathrm{Cu}$-deficient embryos as compared to controls (49). Similar to $\mathrm{Zn}$ and $\mathrm{Cu}$, Mn levels in plasma, whole blood and placental tissue exhibited decreases of equal magnitude in RM patients compared to HP women. We suggest that these lowered levels may have resulted in decreased SOD2 activity and subsequent increases in SOA levels thereby inflicting oxidative damage and miscarriage. However, these results could not be compared owing to the absence of such reports in the literature. However, whole blood Mn concentrations have been shown to be reduced in women with fetal growth restriction, indicating that the element may be important in maintaining fetal growth (50). In addition, findings of a previous study showed lowered umbilical cord whole blood Mn levels in neonates of pre-eclamptic women compared to controls (51).

Results of the present study revealed that the expression level of the $h S S O D l$ gene encoding an antioxidant enzymatic marker in the placental tissue of RM women relative to HP women was significantly downregulated by almost $54 \%$. The currently observed depletion of SOD1 activity, and its lowered gene expression levels may have been caused by a direct damaging effect of the enzyme molecules or DNA damage incurred by the uncontrolled generation of ROS in RM patients, thereby leading to the accumulation of enzyme substrates and downregulation of transcription and translation processes. To this end, the increased generation of SOA to biologically dangerous levels, has been shown to activate key cell hallmark events including mitochondrial alterations and DNA damage $(4,41)$, and may have in turn, triggered a programmed cell death (apoptotic) process. In this context, SOD1 loss has been previously reported to induce the phosphorylation of a DNA damage marker $(\gamma-\mathrm{H} 2 \mathrm{AX})$, and upregulated $\mathrm{p} 21$, a target gene of p53, in fibroblasts (52). Notably, the SOD1-ablated fibroblasts exhibited loss of mitochondrial membrane potential and enhanced mitochondrial ROS generation (52).
In conclusion, the present study provided data that revealed significant decreases in blood and placental tissue of SOD1 and SOD2 activation, as well as markedly reduced placental hsSODl gene expression levels in RM patients relative to HP women. The resultant increased generation of SOA and subsequent OS may have been a major causative factor of miscarriage. Although many studies have reported on the importance of the bioavailability of sufficient amounts of $\mathrm{Cu}, \mathrm{Zn}$ and $\mathrm{Mn}$ as micronutrients necessary for antioxidant function, placental development, cell division and differentiation, embryogenesis, fetal growth and development, and a healthy course and outcome of pregnancy, clinical trial studies related to their supplemental use in preventing RM and other pregnancy-related disorders are scarce, if not absent altogether. In this context, the dietary intake of $\mathrm{Cu}$ in 19 to 24-year-old women has been documented as generally below recommended levels and may cause problems during pregnancy when requirements increase (53). Furthermore, $\mathrm{Mn}$ is one of the least investigated micronutrients and clinical trials regarding its supplementary use are not available (53). In light of the results of the present study, the supplementary use of $\mathrm{Zn}$, $\mathrm{Cu}$ and $\mathrm{Mn}$ may be of beneficial use in patients of RM prior to and throughout pregnancy.

\section{Acknowledgements}

This study was financially supported by King Saud University, Vice Deanship of Research Chairs.

\section{References}

1. Valko M, Leibfritz D, Moncol J, Cronin MT, Mazur M and Telser J: Free radicals and antioxidants in normal physiological functions and human disease. Int J Biochem Cell Biol 39: 44-84, 2007.

2. Al-Gubory KH, Fowler PA and Garrel C: The roles of cellular reactive oxygen species, oxidative stress and antioxidants in pregnancy outcomes. Int J Biochem Cell Biol 42: 1634-1650, 2010.

3. Marnett LJ: Oxyradicals and DNA damage. Carcinogenesis 21: 361-370, 2000.

4. Aboul-Soud MA, Al-Othman AM,El-Desoky GE, Al-Othman ZA, Yusuf K, Ahmad J and Al-Khedhairy AA: Hepatoprotective effects of vitamin E/selenium against malathion-induced injuries on the antioxidant status and apoptosis-related gene expression in rats. J Toxicol Sci 36: 285-296, 2011.

5. Pham-Huy LA, He H and Pham-Huy C: Free radicals, antioxidants in disease and health. Int J Biomed Sci 4: 89-96, 2008.

6. Cadenas E and Davies KJ: Mitochondrial free radical generation, oxidative stress, and aging. Free Radic Biol Med 29: 222-230, 2000.

7. Tu BP and Weissman JS: Oxidative protein folding in eukaryotes: Mechanisms and consequences. J Cell Biol 164: 341-346, 2004.

8. Griendling KK, Sorescu D and Ushio-Fukai M: NAD(P)H oxidase: Role in cardiovascular biology and disease. Circ Res 86: 494-501, 2000

9. Touyz RM, Chen X, Tabet F, Yao G, He G, Quinn MT, Pagano PJ and Schiffrin EL: Expression of a functionally active gp91phox-containing neutrophil-type $\mathrm{NAD}(\mathrm{P}) \mathrm{H}$ oxidase in smooth muscle cells from human resistance arteries: Regulation by angiotensin II. Circ Res 90: 1205-1213, 2002.

10. Raijmakers MT, Burton GJ, Jauniaux E, Seed PT, Peters WH, Steegers EA and Poston L: Placental NAD(P)H oxidase mediated superoxide generation in early pregnancy. Placenta 27: 158-163, 2006.

11. Dröge W: Free radicals in the physiological control of cell function. Physiol Rev 82: 47-95, 2002

12. Liou W, Chang LY, Geuze HJ, Strous GJ, Crapo JD and Slot JW: Distribution of $\mathrm{CuZn}$ superoxide dismutase in rat liver. Free Radic Biol Med 14: 201-207, 1993.

13. Weisiger RA and Fridovich I: Mitochondrial superoxide simutase. Site of synthesis and intramitochondrial localization. J Biol Chem 248: 4793-4796, 1973. 
14. Branch DW, Gibson $M$ and Silver RM: Clinical practice. Recurrent miscarriage. N Engl J Med 363: 1740-1747, 2010.

15. Carrington B, Sacks G and Regan L: Recurrent miscarriage: Pathophysiology and outcome. Curr Opin Obstet Gynecol 17 591-597, 2005

16. Ford HB and Schust DJ: Recurrent pregnancy loss: etiology, diagnosis, and therapy. Rev Obstet Gynecol 2: 76-83, 2009.

17. Arredondo F and Noble LS: Endocrinology of recurrent pregnancy loss. Semin Reprod Med 24: 33-39, 2006.

18. Gupta S, Agarwal A, Banerjee J and Alvarez JG: The role of oxidative stress in spontaneous abortion and recurrent pregnancy loss: a systematic review. Obstet Gynecol Surv 62: 335-347, quiz 353-354, 2007

19. Agarwal A, Gupta S and Sikka S: The role of free radicals and antioxidants in reproduction. Curr Opin Obstet Gynecol 18: 325-332, 2006

20. Biri A, Kavutcu M, Bozkurt N, Devrim E, Nurlu N and Durak I: Investigation of free radical scavenging enzyme activities and lipid peroxidation in human placental tissues with miscarriage. J Soc Gynecol Investig 13: 384-388, 2006.

21. Burton GJ, Hempstock J and Jauniaux E: Oxygen, early embryonic metabolism and free radical-mediated embryopathies. Reprod Biomed Online 6: 84-96, 2003.

22. Poston L and Raijmakers MT: Trophoblast oxidative stress, antioxidants and pregnancy outcome - a review. Placenta 25 (Suppl A): S72-S78, 2004.

23. Sane AS, Chokshi SA, Mishra VV, Barad DP, Shah VC and Nagpal S: Serum lipoperoxides in induced and spontaneous abortions. Gynecol Obstet Invest 31: 172-175, 1991.

24. El-Far M, El-Sayed IH, El-Motwally AE, Hashem IA and Bakry N: Serum levels of TNF-alpha and antioxidant enzymes and placental TNF-alpha expression in unexplained recurrent spontaneous miscarriage. J Physiol Biochem 65: 175-181, 2009.

25. Talat TK: The relationship between serum copper, zinc and glutathione peroxidase with malondialdehyde in women with unexplaianed recurrent miscarriage. Kufa Med J 12: 29-37, 2009.

26. Abdul-Barry J, Al-Rubai SA and Qasim QA: Study of oxidant - antioxidant status in recurrent spontaneous abortion. Thi-Qar Med J 5: 35-46, 2011

27. Ghneim HK and Alshebly MM: Biochemical markers of oxidative stress in Saudi women with recurrent miscarriage. J Korean Med Sci: 31: 98-105, 2016

28. Jenkins C, Wilson R, Roberts J, Miller H, McKillop JH and Walker JJ: Antioxidants: their role in pregnancy and miscarriage. Antioxid Redox Signal 2: 623-628, 2000.

29. de Haan JB, Cristiano F, Iannello R, Bladier C, Kelner MJ and Kola I: Elevation in the ratio of $\mathrm{Cu} / \mathrm{Zn}$-superoxide dismutase to glutathione peroxidase activity induces features of cellular senescence and this effect is mediated by hydrogen peroxide. Hum Mol Genet 5: 283-292, 1996.

30. Al-Sheikh YA and Ghneim HK: 'The effect of micronutrients on superoxide dismutase in senescent fibroblasts'. Cell Biochem Funct 29: 384-393, 2011.

31. Johnston RB Jr, Keele BB Jr, Misra HP, Lehmeyer JE, Webb LS, Baehner RL and RaJagopalan KV: The role of superoxide anion generation in phagocytic bactericidal activity. Studies with normal and chronic granulomatous disease leukocytes. J Clin Invest 55: 1357-1372, 1975

32. Osada H, Watanabe Y, Nishimura Y, Yukawa M, Seki K and Sekiya S: Profile of trace element concentrations in the feto-placental unit in relation to fetal growth. Acta Obstet Gynecol Scand 81: 931-937, 2002.

33. Saquib Q, Attia SM, Siddiqui MA, Aboul-Soud MA, Al-Khedhairy AA, Giesy JP and Musarrat J: Phorate-induced oxidative stress, DNA damage and transcriptional activation of p53 and caspase genes in male Wistar rats. Toxicol Appl Pharmacol 259: 54-65, 2012.
34. Bradford MM: A rapid and sensitive method for the quantitation of microgram quantities of protein utilizing the principle of protein-dye binding. Anal Biochem 72: 248-254, 1976.

35. Morris JM, Gopaul NK, Endresen MJ, Knight M, Linton EA, Dhir S, Anggård EE and Redman CW: Circulating markers of oxidative stress are raised in normal pregnancy and pre-eclampsia. Br J Obstet Gynaecol 105: 1195-1199, 1998.

36. Myatt L and Cui X: Oxidative stress in the placenta. Histochem Cell Biol 122: 369-382, 2004

37. Cindrova-Davies T: Gabor Than Award Lecture 2008: pre-eclampsia - from placental oxidative stress to maternal endothelial dysfunction. Placenta 30 (Suppl A): S55-S65, 2009.

38. Kehrer JP: The Haber-Weiss reaction and mechanisms of toxicity. Toxicology 149: 43-50, 2000 .

39. Liochev SI: The mechanism of 'Fenton-like' reactions and their importance for biological systems. A biologist's view. Met Ions Biol Syst 36: 1-39, 1999.

40. Agarwal A: oxidants and antioxidants in human fertility. Middle East Soc Fertil J 9: 187-197, 2004.

41. Yiyenoğlu ÖB, Uğur MG, Özcan HÇ, Can G, Öztürk E, Balat Ö and Erel Ö: Assessment of oxidative stress markers in recurrent pregnancy loss: A prospective study. Arch Gynecol Obstet 289: 1337-1340, 2014.

42. Black RE: Micronutrients in pregnancy. Br J Nutr 85 (Suppl 2): S193-S197, 2001

43. Jameson S: Zinc status in pregnancy: the effect of zinc therapy on perinatal mortality, prematurity, and placental ablation. Ann N Y Acad Sci 678: 178-192, 1993.

44. Pathak P, Kapoor SK, Kapil U, Joshi, YK and Dwivedi SN: Copper nutriture amongst pregnant women in a rural area of India. Eastern J Med 8: 15-17, 2003.

45. Izquierdo Alvarez S, Castañón SG, Ruata ML, Aragüés EF, Terraz PB, Irazabal YG, González EG and Rodríguez BG: Updating of normal levels of copper, zinc and selenium in serum of pregnant women. J Trace Elem Med Biol 21 (Suppl 1): 49-52, 2007.

46. Liu J, Yang H, Shi H, Shen C, Zhou W, Dai Q and Jiang Y: Blood copper, zinc, calcium, and magnesium levels during different duration of pregnancy in Chinese. Biol Trace Elem Res 135: $31-37,2010$

47. Alebic-Juretic A and Frkovic A: Plasma copper concentrations in pathological pregnancies. J Trace Elem Med Biol 19: 191-194, 2005.

48. Shakour-Shahabi L, Abbasali-Zadeh S and Rashtchi-Zadeh N: Serum level and antioxidant activity of ceruloplasmin in preeclampsia. Pak J Biol Sci 13: 621-627, 2010.

49. Keen CL, Uriu-Hare JY, Hawk SN, Jankowski MA, Daston GP, Kwik-Uribe CL and Rucker RB: Effect of copper deficiency on prenatal development and pregnancy outcome. Am J Clin Nutr 67 (Suppl 5): S1003-S1011, 1998.

50. Vigeh M, Yokoyama K, Ramezanzadeh F, Dahaghin M, Fakhriazad E, Seyedaghamiri Z and Araki S: Blood manganese concentrations and intrauterine growth restriction. Reprod Toxicol 25: 219-223, 2008.

51. Jones EA, Wright JM, Rice G, Buckley BT, Magsumbol MS, Barr DB and Williams BL: Metal exposures in an inner-city neonatal population. Environ Int 36: 649-654, 2010.

52. Lei XG, Zhu JH, McClung JP, Aregullin M and Roneker CA: Mice deficient in $\mathrm{Cu}, \mathrm{Zn}$-superoxide dismutase are resistant to acetaminophen toxicity. Biochem J 399: 455-461, 2006.

53. Mistry HD and Williams PJ: The importance of antioxidant micronutrients in pregnancy. Oxid Med Cell Longev 2011: 841749, 2011. 